\title{
The Effect of Firm Size, Leverage, Profitability, Ownership Structure, and Firm Age on Enterprise Risk Management Disclosures
}

\author{
Choiru Rujiin ${ }^{* 1}$ and Sukirman ${ }^{2}$ \\ ${ }^{1}$ Kantor Akuntan Publik Tasnim, Fardiman, Sapuan, Nuzuliana, Ramdan \& Rekan Cabang Semarang \\ ${ }^{2}$ Accounting Department, Faculty of Economics, Universitas Negeri Semarang
}

\section{ARTICLE INFO}

\section{Article History:}

Received August $18^{\text {th }}, 2019$

Accepted June $30^{\text {th }}, 2020$

Available July $30^{\text {th }}, 2020$

\section{Keywords:}

firm size; leverage;

profitability; firm age

\begin{abstract}
This study aims to examine the effect of firm size, leverage, profitability, domestic institutional ownership structure, foreign ownership structure, local individual ownership structure, and firm age on enterprise risk management disclosure. The population in this study was a manufacturing firm registered on the IDX in 2013-2017 with a purposive sampling technique and produced 7 samples with 35 units of analysis. The data in this study are secondary data in the form of annual reports with data collection techniques in the form of documentation. This study uses multiple regression data analysis technique. The results showed that firm size and firm age had a significant positive effect on enterprise risk management disclosure, while leverage, profitability, domestic institutional ownership structure, foreign ownership structure, local individual ownership structure had a significant negative effect towards enterprise risk management disclosures. The conclusion of this study is that only firm size and firm age have a significant positive effect on enterprise risk management disclosure, which means that the larger the size of the firm and the longer the firm stands, the higher the disclosure.
\end{abstract}

\section{INTRODUCTION}

Risk is an unexpected situation and can be attached to any activities carried out by a company. As in some of the following incidents including cases of financial engineering and accounting malpractice that had shocked the business world at that time occurred in Enron (2001) and Worldcom (2002) companies because the two companies are the largest companies in the world. In addition to the cases experienced by Enron and Worldcom in Indonesia, it also felt the impact of the global crisis 2008 caused by the encouragement of the people of the United States in the life of consumerism beyond their limits. Because of the global crisis, Indonesia was also affected, especially by companies in Indonesia. In Indonesia, companies faced problems in dealing with currency trading problems which cause institutions to have a refreshing system, reorganize, and have to close down (Endah \& Diani, 2013). This means that the process of risk management is very important for companies, because in addition to maintaining the

\footnotetext{
*E-mail: rujiinchoiru@gmail.com

_Address: Jalan Jati Raya Utama 2 No. 8, Banyumanik, Semarang, Central Java, Indonesia
}

stability of company also to increase trust for external groups of institutions.

Risk management is an approach to minimize the consequences of problems that are experienced at anytime so that corporate goals will be more easily achieved. Risk management system is believed to be able to help company achieve its business goals, assist financial reporting and save corporate reputation effectively (Ratnawati, 2012). According to Abdullah et al., (2017) that disclosure of risk management is very important for non-financial companies, because it can also be useful for regulatory body to develop more detailed guidelines on disclosure of financial risk management in non-financial companies in the future. In the world, there are two institutions that regulate or issue a standard in the process of risk management control that can be applied in all company characteristics, the first is COSO (Committee of Sponsoring Organizations of the Treadway Commission) in 2004 brought up a framework on risk management called Enterprise Risk Management Integrated Framework 2004. The framework is a development of the COSO Internal Control Integrated Framework that was released in 1992.

The second is ISO (International Organization for Standardization) 31000 which contains standards for p-ISSN 2252-6765 e-ISSN 2502-6216 
the implementation of risk management of a company. Both are standards that have been recognized by the world and can be applied in all types with varying risks. In Indonesia, there is also Capital Market and Financial Institution Supervisory Agency (currently FSA), which issued kep-347/BL/2012 regarding financial presentation and reporting, one of which regulates the disclosure of risk management. This rule does not replace PSAK Number 50 (revised) that applies but only as a companion that must also be obeyed by the issuer of the company in the financial presentation and reporting.

The meaningful of the problem notification began at the beginning of 1998 and the focus on risk disclosure has increased since the publication of IFRS 7, January 1, 2007 (Taufani et al., 2016) Submitting the problem can be stated in agency's annual report. The implementation of risk management has now become a worldwide concern and has begun to be applied by companies in both Indonesia and the world. A survey carried out by Deloitte (2009) showed 111 financial companies which have been surveyed in Latin America 36\% of companies have run risk management disclosures and $23 \%$ of companies have planned to run them. Desender (2009) found average enterprise risk management result for 97 companies at $36 \%$. The survey indicates that the risk management disclosure is still very low and proven that both surveys still show score below 50\% (Sari, 2013). Risk management disclosure has benefits for internal and external institutions. With enterprise risk management disclosure, the society can ease the problems experienced by institutions both financial and operational problems.

Studies on institutional risk management disclosure still show uncertain results, such as research conducted by Sulistyaningsih \& Gunawan (2016) \& Razali et al., (2012) show that firm size has no impact on the transparency of institutional issue management. Sarwono et al.(2018), Hasina et al.(2018), Jannah (2016), Neri et al, (2018), Jia et al.(2016), and Saidet al. (2018) explained that firm size has a positive impact on the transparency of institutional issue management. Whereas Tessema (2016) showed that firm size has a negative impact on the transparency of institutional issue management. Syifa (2013), Razali et al.(2012), and Probohudono et al.(2013) explained that leverage does not have an impact on the disclosure of institutional issue management transparency. Kumalasari et al.(2014) and Sarwono et al.(2018) explained that leverage has a positive impact on the transparency of institutional issue management. Marhaeni \& Yanto (2015), Jia et al.(2016), and Tessema (2016) explained that leverage has a negative impact on the transparency of institutional issue management. Sarwono et al.(2018), Razali et al.(2012), \& Probohudono et al.(2013) explained that profit does not affect the transparency of of institutional issue management. Kumalasari et al.(2014), Jannah (2016) explained that profitability has an impact on the transparency of institutional issue management. Prayoga \& Almilia (2013) the result of the study shows that domestic institutional ownership has an impact on the transparency of institutional issue management. Taufani et al.(2016) showed that the domestic institutional ownership does not have a significant positive effect on the transparency of institutional issue management. Sari (2013) explained that ownership centralization has a positive impact on the transparency of institutional issue management. Probohudono et al.(2013) firm age does not have an impact on the institutional issue management.

Based on the phenomena listed, this research intends to examine the effect of agency size, leverage, profitability, structure of domestic institutional ownership, structure of foreign ownership, and structure of local individual ownership. Since in current developments foreigners are more in control of the stock market in Indonesia (CNBC Indonesia, 2019) and increasingly intensive socialization to grow new domestic investors and firm age towards transparency in managing institutional issues. This study illustrates expansion and merging based on the previous studies with a longer time span of five years from 2013-2017 compared to the previous studies, with novelty on variables of foreign ownership structure and local individual ownership structures. There is no research that examines the variables of firm size, leverage, profitability, structure of domestic institutional ownership, foreign ownership structure, ownership structure of local individuals and firm age together.

This research is based on two main theories namely agency theory and signaling theory. Corporate governance factors have the potency to influence the level and quality of enterprise risk management openness in the company (Buckby et al. 2015). By doing risk management, manager will be more controlled in managing the company and shareholders will know the condition of the company better.

Company will give a signal to stakeholders because there is information asymmetry about corporate situation. Signaling theory explains the motivation of agencies in delivering financial statement information to outside parties (Prayoga \& Almilia, 2013). With the publication of a good annual report and high risk management disclosures, investors will get a signal to assess the company so that it can improve the quality of decisions to be taken. The level of success of a company in running its business is always related to how the company handles the risks it faces. Rasidet al.(2014) argued that there is no profitable business if risks are managed separately, therefore risks must be managed with the implementation of good risk management. Meanwhile, Bogodistov \& Veit (2017) defined risk management as a framework for resolving and managing risks for uncertain events that can provide benefits and advantages to the institution.

Firm age explains small or large an institution. Agency theory explains that the larger size of an institution, the wider the transparency of problem management, because the size of a large company allows a lot of risk to occur and there are a number of investors who play a role in the acquisition of institutional assets, so companies need to make risk management disclosure as a form of accountability to investors that the companies are able to manage the capital and risks faced and vice versa. The studies conducted by Neri et al. (2018), Jia et al. (2016), and Said et al.(2018) show that firm size has a 
significant positive effect on risk management.

\section{$\mathrm{H}_{1}$ : Firm size has a positive effect on Enterprise Risk Management disclosure}

Leverage calculates how much the institution uses its debt to finance corporate operations. A high level of leverage indicates that the capital structure in an institution is derived more from debt than company equity. Agencies that use debt have obligations for interest expenses and debt principal expenses (Devi et al. 2017). Agency theory explains that the greater the leverage, the smaller the enterprise risk management transparency implemented by agency managers. This is because institutions with huge level of liability will be more risky so that managers will try to cover up these risks by making low disclosures to attract investors in order to keep investing in the institution. Thus, the costs that should have been incurred to finance the ERM disclosure process can be used to pay off corporate debt and vice versa. Research conducted by Jia et al.(2016), Tessema (2016) and Marhaeni \& Yanto (2015) explain that leverage has a significant and negative effect related to transparency in the management of instances.

\section{$\mathrm{H}_{2}$ : Leverage has a negative effect on disclosure of Enterprise Risk Management}

Profit is the level of earning that can be generated by the company as an achievement of the business activities of a company. Agency theory explains that the more profit an institution gets, managers will reveal more detailed enterprise risk management to attract investors' desire and trust to invest in institutions. This is because more and more profits are obtained by the institution indicating that the institution has good prospects for carrying out its business. With good conditions, the company makes transparency in problem management in detail in order to increase firm value in the eyes of investors. Research conducted by Kumalasari et al.(2014), Jannah(2016), and Abdullah et al.(2017) explain that profitability has a positive effect on the transparency of company issue management.

\section{$\mathrm{H}_{3}$ : Profitability has a positive effect on disclosure of Enterprise Risk Management}

Domestic institutional ownership is the proportion of shares ownership owned by institutions or entities that are domiciled in Indonesia. This ownership can be owned by banks, insurance companies, cooperatives, investment companies or other business entities in Indonesia. Based on signaling theory, it shows that the more shares owned by domestic institutions, the higher the disclosure of enterprise risk management implemented by institutional managers. This aims to signal a positive signal to investors to keep trusting the company that the company is responsible for the capital managed, even though this is reflected in the reports disclosed by the company to investors and vice versa. Prayoga \& Almilia (2013) the result which indicates that the variable of domestic institutional variable has an impact on the transparency of corporate issue management.

\section{$\mathrm{H}_{4}$ : Structure of domestic institutional ownership has a positive effect on the disclosure of Enter- prise Risk Management}

Structure of foreign ownership is the level of shares owned by institutions or individuals which are abroad that invest in certain companies. Foreign ownership according to Law No. 25 of 2007 concerning investment in article 1 number 6 is individuals who are foreign citizens, foreign business institutions, and foreign leaders who invest domestically. Based on signaling theory, it shows that the more ownership of foreign shares, the wider the transparency of institutional issue management implemented by institutional managers. This aims to signal a positive signal to investors to continue to believe in the company that the company is responsible for the capital it manages which is disclosed in every report issued by the company either quarterly, semester, or yearly and vice versa.

\section{$\mathrm{H}_{5}$ : Structure of foreign ownership has a positive effect on disclosure of Enterprise Risk Manage- ment}

Local individual ownership is the level of ownership of a particular institution for individuals who are Indonesian citizens. Based on signaling theory, it shows that the more shares owned by local individuals, the higher the disclosure of enterprise risk management implemented by institutional managers. This aims to signal a positive signal to investors to continue to believe in the company that the company is responsible for the capital it manages which is disclosed in every report or positive news about the company's condition and vice versa.

\section{$\mathrm{H}_{6}$ : Local individual ownership structure has a posi- tive effect on the disclosure of Enterprise Risk Management}

Firm age is how long the institution has been standing in running its business. Firm age is a matter of concern to investors in investing, firm age indicates that the institution continues to survive and is a testimony that the agency is able to flank and can pick out the opportunities that exist in the economy (Bestivano, 2013). Signaling theory shows that the longer the institution is established, the more extensive the disclosure of enterprise risk management is carried out by agency managers. This is related to the growing maturity of the agencies will certainly have more abundant experience in dealing with risks by continuing to operate the company until now. With this experience, of course, company managers already have the right strategy implemented in the company so as to maintain the stability of the company and increase company profits. With such a good condition, the manager will reveal the enterprise risk management well to give a positive signal in order to attract investors to invest in the institutions they run and vice versa. Research conducted by Solomon et al. (2000), Marshall \& Weetman (2002) and Abraham \& Cox (2007) show that firm age has a positive impact on the transparency of company issue management. 
$\mathrm{H}_{7}$ : Firm age has a positive effect on the disclosure of Enterprise Risk Management

\section{RESEARCH METHODS}

This type of research described quantitative research using secondary information with a population of 172 companies. To maintain the unity of data, the researchers only took manufacturing institutions to find out the development of corporate risk management disclosures in 2013-2017. The samples in this research were 7 institutions with 35 units of analysis in a span of five years. The following is the sampling table presented in Table 1.

Variables of enterprise risk management, firm size, leverage, profitability, domestic institutional ownership structure, foreign ownership structure, local individual ownership structure, and firm age are explained in Table 2.

The data in this research was secondary information in the form of annual reports of institutions listed on the Indonesia Stock Exchange (IDX) for the period
2013-2017 obtained by documentation on the Indonesian Stock Exchange website (www.idx.co.id). The information study method used was the classical assumption test (linearity test, normality test, multicollinearity test, autocorrelation test, and heteroscedasticity test) followed by multiple regression tests using IBM SPSS Statistics 23 and hypothesis testing (coefficient of determination and t test) ) with a significance level of $5 \%$.

\section{RESULTS AND DISCUSSIONS}

The results of the classical assumption test that is linearity test using scatter plot test show that all dependent variables form a straight line to the independent variable. The result of the normality test using Kolmogorov-Smirnov explains a number of 0.200 which shows $\geq 0.05$ so that the data is spread normally. The result of the multicollinearity test explains that all dependent variables have a tolerance value $\geq 0.10$ so they are free from multicollinearity. The result of the autocorrelation test by using run test shows the result of 0.489 which shows $\geq 0.05$ so that the data is free from autocorrelation. The result of the heteroscedasticity test using gletser

Table 1. Sampling with Purposive Sampling Technique

\begin{tabular}{clcc}
\hline No & \multicolumn{1}{c}{ Criteria } & Not Fulfilled & Fulfilled \\
\hline 1. & The population of manufacturing agencies listed on IDX & 172 \\
2. & Companies that keep listing in the research year & $(5)$ & 167 \\
3. & $\begin{array}{l}\text { Companies publish annual reports on the IDX during the research period } \\
\text { successively }\end{array}$ & $(24)$ & 143 \\
4. & $\begin{array}{l}\text { Institutions that disclose the structure of share ownership according to the } \\
\text { research criteria }\end{array}$ & $(114)$ & 29 \\
5. Institutions that use rupiah in the financial statements & $(22)$ & 7 \\
\hline \multicolumn{2}{c}{ Total Sample 2013 - 2017 (7 x 5) } & 35 \\
\hline \multicolumn{2}{c}{ Source : IDX and corporate official website (data processed 2019) }
\end{tabular}

Table 2. Operational Definition of Research

\begin{tabular}{|c|c|c|c|}
\hline Variables & Definition & Indicator & Source \\
\hline $\begin{array}{l}\text { Disclosure of Enterprise } \\
\text { Risk Management (ERM) }\end{array}$ & $\begin{array}{l}\text { How extent to which compa- } \\
\text { ny disclose risk management } \\
\text { in annual reports }\end{array}$ & $\begin{array}{l}\text { Number of disclosure items of } \\
\text { ERM/108x100\% } \\
\text { (COSO 2004) }\end{array}$ & $\begin{array}{l}\text { Aprilianto } \\
(2017)\end{array}$ \\
\hline Firm Age (UKP) & $\begin{array}{l}\text { How large the company is } \\
\text { seen from the total assets of } \\
\text { the company }\end{array}$ & Firm Size $=$ Ln Total Asset & $\begin{array}{l}\text { Aprilianto, } \\
(2017)\end{array}$ \\
\hline Leverage (LEV) & $\begin{array}{l}\text { The ability of company to } \\
\text { pay its obligations }\end{array}$ & $\begin{array}{l}\text { Leverage }=\text { total liabilities } / \text { total } \\
\text { equityx } 100 \%\end{array}$ & $\begin{array}{l}\text { Aprilianto, } \\
(2017)\end{array}$ \\
\hline Profitability (PROF) & $\begin{array}{l}\text { The level of profits / profits } \\
\text { obtained by the company }\end{array}$ & $\begin{array}{l}\text { Profitability }=\text { net profit } / \\
\text { sales } 100 \%\end{array}$ & $\begin{array}{l}\text { Aprilianto, } \\
\text { (2017) }\end{array}$ \\
\hline $\begin{array}{l}\text { Domestic Institutional Own- } \\
\text { ership Structure (KID) }\end{array}$ & $\begin{array}{l}\text { Proportion of share owner- } \\
\text { ship by domestic institutions }\end{array}$ & $\begin{array}{l}\text { Ownership of domestic institutions } \\
\text { / total company shares } \times 100 \%\end{array}$ & $\begin{array}{l}\text { Prayoga \& } \\
\text { Almilia } \\
(2013)\end{array}$ \\
\hline $\begin{array}{l}\text { Structure of Foreign Owner- } \\
\text { ship (KA) }\end{array}$ & $\begin{array}{l}\text { Proportion of share owner- } \\
\text { ship by foreigners }\end{array}$ & $\begin{array}{l}\text { Foreign ownership / total company } \\
\text { shares } \times 100 \%\end{array}$ & $\begin{array}{l}\text { Prayoga } \\
\text { \& Almilia } \\
(2013)\end{array}$ \\
\hline $\begin{array}{l}\text { Local Individual Ownership } \\
\text { Structure (KIL) }\end{array}$ & $\begin{array}{l}\text { Proportion of share owner- } \\
\text { ship by local individuals }\end{array}$ & $\begin{array}{l}\text { Local individual ownership / total } \\
\text { company shares } \times 100 \%\end{array}$ & $\begin{array}{l}\text { Prayoga } \\
\text { \& Almilia } \\
\text { (2013) }\end{array}$ \\
\hline Firm Age (UMP) & $\begin{array}{l}\text { How long the company run } \\
\text { its business }\end{array}$ & $\begin{array}{l}\text { Firm age } \\
=\text { Current year - year the company } \\
\text { was founded }\end{array}$ & $\begin{array}{l}\text { Rohmaniyah } \\
\text { (2016) }\end{array}$ \\
\hline
\end{tabular}


test shows that all variables in this research has sig values $\geq 0.05$ so that the data pass the test. The coefficient of determination explains that the independent variable is able to show the dependent variable by $95 \%$. The results of the multiple regression analysis can be shown in Table 3 .

\section{The Effect of Firm Size on Enterprise Risk Manage- ment Disclosures}

The size of the agency has a significant positive impact on the transparency of institutional issue management. Large scale firm allows many problems that arise in the firm, this will have an impact on the extent of disclosure applied by managers. This is in accordance with the agency theory which explains that institutions that have large size are overseen by corporate investors because the amount of risk faced is also greater. To maintain the reputation and good name of the company, managers make transparency in the management of institutional issues well to increase openness and keep maintaining the trust of institutional investors. The result of this study is consistent with studies conducted by Jia et al. (2016), Sari (2013) and Jannah(2016).

\section{The Effect of Leverage on Enterprise Risk Manage- ment Disclosures}

Leverage has a significant negative impact on the transparency of agency problem management. The level of leverage that is slender indicates that the capital structure within the agency is larger sourced from debt than company equity, so that if there are problems related to corporate finance the company will be vulnerable to bankruptcy. Thus, the institutions with a high degree of leverage, managers will try to cover it up to keep getting capital from investors so that the agencies can get the equity for their business activities and can pay their debts. This is in line with agency theory which shows that institutions which have a low leverage will carry out the transparency of agency problem management well. This is to lure investors to invest in institutions and vice versa. The result of this research is in line with the research carried out by Jia et al.(2016), Tessema (2016) and Marhaeni \& Yanto(2015).

\section{The Effect of Profitability on Enterprise Risk Man- agement Disclosures}

Profitability has a significant negative impact on the transparency of agency problem management. Large or small profit level can suggest broad transparency of agency problem management. This is due to companies that have small profits will try to make disclosures in detail. This is since there are a number of risks faced by the company and to maintain the trust of corporate investors that managers have been responsible for the capital they manage so that corporate investors can know the true state of the company from reports and news about the corporate state and as a form of responsibility of managers to institutional stakeholders.

This result contradicts agency theory which shows that the more profit the agency has, the wider the enterprise risk management disclosure implemented by the institution. This can be experienced because basically agencies with a high level of profit tend to have less risky faced so the company does not discuss these risks in the annual report which causes the extent of disclosure to be low. This research is in accordance with research conducted by Jannah (2016) and Kumalasari et al.(2014).

\section{The Effect of Domestic Institutional Ownership Structure on Enterprise Risk Management Disclo- sures}

The structure of the domestic institutional ownership has a negative effect on the transparency of enterprise risk management. This is due to low ownership of shares by domestic institutions, allowing managers to disclose more detailed enterprise risk management in order to attract investors from domestic institutions to invest in institutions thereby it is able to increase corporate capital for operational activities. Conversely, if the ownership of domestic institutions is already high, managers feel that it is necessary to provide returns in

Table 3. Results of Multiple Linear Regression

\begin{tabular}{clcccc}
\hline No & \multicolumn{1}{c}{ Hypothesis } & B & sig & a & Results \\
\hline 1 & $\begin{array}{l}\text { Firm size has a positive effect on the disclosure of enterprise risk man- } \\
\text { agement. }\end{array}$ & 0.380 & 0.002 & 0.05 & Accepted \\
2 & $\begin{array}{l}\text { Leverage has a negative effect on the disclosure of enterprise risk man- } \\
\text { agement. }\end{array}$ & -0.144 & 0.019 & 0.05 & Accepted \\
3 & $\begin{array}{l}\text { Profitability has a positive effect on the disclosure of enterprise risk } \\
\text { management. }\end{array}$ & -0.126 & 0.007 & 0.05 & Rejected \\
4 & $\begin{array}{l}\text { The structure of domestic institutional ownership has a positive effect } \\
\text { on the disclosure of enterprise risk management. }\end{array}$ & -0.588 & 0.000 & 0.05 & Rejected \\
& $\begin{array}{l}\text { The structure of foreign ownership has a positive effect on the disclosure } \\
\text { of enterprise risk management. }\end{array}$ & -0.917 & 0.000 & 0.05 & Rejected \\
6 & $\begin{array}{l}\text { The structure of local individual ownership has a positive effect on the } \\
\text { disclosure of enterprise risk management. }\end{array}$ & -0.291 & 0.000 & 0.05 & Rejected \\
7 & $\begin{array}{l}\text { Firm age has a positive effect on the disclosure of enterprise risk man- } \\
\text { agement. }\end{array}$ & 0.723 & 0.000 & 0.05 & Accepted \\
\hline
\end{tabular}


the form of dividends to maintain investor trust from domestic institutions. This is in line with agency theory which shows that investors invest in institutions to get returns from capital gains or dividends distributed by the agency.

This result is not in accordance with signaling theory which shows that the more abundant the ownership of domestic institutions, the higher the enterprise risk management disclosure. This can happen because not all facts are in accordance with existing theories, for example, in this case there are sometimes investors who are more looking for dividends for their investment, but not infrequently also investors who do not pay attention to the dividends they get. The result of this research is in line with the research conducted by Prayoga \& Almilia (2013).

\section{The Effect of Foreign Ownership Structure on Enter- prise Risk Management Disclosures}

The structure of foreign ownership has a negative impact on the transparency of agency problem management. The direction of the hypothesis testing is negative, where the less foreign ownership; the more transparent the management of agency problems will be. This intends to lure investors to invest in the institutions concerned. With high investor trust to the company, the institution will obtain equity for the company to operate so that it can provide high returns to investors in the form of capital gains and dividends.

This is not in accordance with signaling theory which shows that the more abundant the ownership of shares by foreigners, the more detailed is the enterprise risk management disclosure carried out by managers. This can be experienced because of a matter, for example, with a high level of foreign ownership which is balanced with a high level of profitability does not guarantee disclosure which is done also high as happened by PT Kalbe Farma Tbk. This is because maybe the relevant institution has no risk included in the COSO disclosure items such as access risk to the capital market or other risks so the extent of disclosure to 2004 is as low.

\section{The Effect of Local Individual Ownership Structure on Enterprise Risk Management Disclosures}

The structure of local individual ownership has a negative impact on the transparency of agency problem management. Less and less local individual ownership, the transparency of agency issue problem management will be more detailed. This intends to lure investors to invest in the concerned institutions and vice versa. In the investment world, there are several types of investors namely investors who pay attention to the fundamentals of the company and investors who are after dividends.

When the local individual investors are still low, then the company will disclose high enterprise risk management to attract investors who look at the company's fundamentals based on the annual reports published. However, if the local individual ownership is already high, the company can distribute dividends to attract investors with the type of dividend hunter. This is done by reducing the extent of enterprise risk management disclosures so that the costs that should be incurred for making disclosures can be allocated to dividends to be distributed to the investors so that the agencies can get more power to carry out their business activities.

This is not in accordance with signaling theory which shows that the more abundant the ownership of shares by local individuals, the more detailed the enterprise risk management disclosure that is carried out by the managers. This can happen to retail investors who are looking for dividends to be distributed by the company, where they will invest their capital if companies often distribute dividends. Thus, when local individual investors are already high, to maintain their capital, the company can distribute dividends both interim and at the end of the year.

\section{The Effect of Firm Age on Enterprise Risk Manage- ment Disclosures}

Firm age has a positive impact on the transparency of enterprise risk management. This shows that the longer the institution stands, the more it shows the maturity of the company in overcoming the risks faced, which is then outlined in extensive and detailed disclosure of enterprise risk management in the company's annual report. In addition, by doing this, it can increase company transparency which can increase the trust of corporate investors that the agency has done good corporate governance properly. This is in line with signaling theory which explains that the level of corporate maturity is shown by how the company responds to each the risks it faces, the better the company in managing the risks it faces, the signals given to investors will also be better in this case is a positive signal and vice versa. The result of this study is in line with the studies conducted by Solomon et al. (2000), Marshall \& Weetman (2002) and Abraham \& Cox (2007).

\section{CONCLUSIONS}

This study examines scientifically the impact of firm size, leverage, profitability, the structure of domestic institutional ownership, the structure of foreign ownership, the structure of local individual ownership and firm age on the transparency of agency problem management. The results of the study explain that the greater the scale of the institution and the more mature the institution established can have a significant positive impact on the transparency of agency problem management.

While the greater the leverage, the level of profit proxied by NPM, the number of structure of domestic institutional ownership, foreign ownership structure, and local individual ownership structures can have a significant negative effect on the transparency of agency problem management. The disclosure of enterprise risk management in the digital era as it is now very important to do in addition to supporting company performance can also increase transparency to corporate investors.

The limitation in this study is that too few companies disclose ownership structures in detail, resulting in fewer sample institutions. Suggestions for future rese- 
arch are expected to be able to add new variables such as employee ownership structure and if primary research can use guidelines from ISO 31000 to assess the extent of enterprise risk management disclosure so that it can be known the comparison between the use of the COSO 2004 guidelines with ISO 31000.

\section{REFERENCES}

Abdullah, M., Shukor, Z. A., Mohamed, Z. M., Ahmad, A. (2017). Risk Management Disclosure: A Study on the Effect of Voluntary Risk Management Disclosure Toward Firm Value. Journal of Applied Accounting Research. 16(3), 400-432. https://doi.org/10.1108/JAAR-102014-0106

Abraham, S. \& Cox, P. (2007). Analysing the Determinants of Narrative Risk Information in UK FTSE 100 Annual Reports. The British Accounting Review, 39(3), 227-248.

Bestivano, W. (2013). Enterprise risk management: a capability-based perspective. Journal of Risk Finance, 18(3), 234251. https://doi.org/10.1108/JRF-10-2016-0131 .

Bogodistov, Y.,\& Wohlgemuth, V. (2017). Enterprise Risk Management: a Capability-Based Perspective. The Journal of Risk Finance, 18(3). https://doi.org/10.1108/ JRF-10-2016-0131

Buckby, S.,Gallery, G.,\& Ma,J. (2015).An Analysis of Risk Management Disclosures: Australian Evidence.Managerial Auditing Journal, 30(8/9), 812 - 869. https:// dx.doi.org/10.1108/MAJ-09-2013-0934

Deloitte.(2009). GlobalRiskManagement Survey. SixthEditionRisk Management In The Sportlight. New York: Deloitte Touche Tohmatsu.

Devi, S.,Budiasih, I. G. N.,\&Badera, I. D. N.(2017). Pengaruh Pengungkapan Enterprise Risk Management dan Pengungkapan Intelecctual Capital Terhadap Nilai Perusahaan. Jurnal Akuntansi Keuangan dan Keuangan Indonesia. 14(1), 20-45.

Desender, K. A., \& Lafuente, E. (2009). The Influence Of Board Composition, Audit Fees And Ownership Concentration On Enterprise Risk Management. SSRN Electronic Journal. https://doi.org/10.2139/ssrn.1495856

Endah, N.,\& Diani, Y. (2013). Faktor-Faktor yang Mempengaruhi Pengungkapan Risk Management Commitee. Accounting Analysis Journal, 2(2), 132-138.

Hasina, G.,Nazar, M. R.,\& Budiono, E. (2018). Pengaruh Ukuran Dewan Komisaris, Leverage dan Ukuran Perusahaan Terhadap Pengungkapan Enterprise Risk Management. E-Proceeding of Management. 5(2), 2402.

Indonesia, R. (2007). Undang-Undang No. 25 Tahun 2007 tentang Penanaman Modal. Jakarta: Sekretariat Negara.

Jannah, I. M. M. (2016). Pengaruh Tingkat Leverage, Profitabilitas, dan Ukuran Perusahaan Terhadap Pengungkapan Manajemen Risiko. Doctoral dissertation, STIE Perbanas Suranbaya.

Jia, J., Munro, L., \& Buckby, S. (2016). A finer-grained approach to assessing the "quality" ("quantity" and "richness") of risk management disclosures.Managerial Auditing Journal, 31(8/9), 770-803. https://dx.doi. org/10.1108/MAJ-12-2014-1135

Kevin, A. (2019). Ekonomi Indonesia Kuat, Tapi Rentan Digoyang Investor Asing. Retrieved June 5, 2019, from https://www.cnbcindonesia.com/market/20190605172217-17-76879/ekonomi-indonesiakuat-tapi-rentan-digoyang-investor-asing

Kumalasari, M., Subowo,\& Anisykurlillah, I.(2014). FaktorFaktor yang Berpengaruh Terhadap Luas Pengungka- pan Manajemen Risiko. Accounting Analysis Journal, $3(1), 18-25$.

Neri,L.,Elshandidy, T.,\& Guo, Y.(2018). Determinants and impacts of risk disclosure quality: evidence from China.Journal of Applied Accounting Research, 19(4), 518536 https://doi.org/10.1108/JAAR-07-2016-0066

Marhaeni, T.,\& Yanto,H. (2015). Determinan Pengungkapan Enterprise Risk Management (ERM) pada Perusahaan Manufaktur. Accounting Analysis Journal, 4(4), 1-22.

Marshall, A.P. \& Weetman, P. (2002). Information Asymmetry in Disclosure of Foreign Exchange Risk Management: Can Regulation be Effective?. Journal of Economics and Business, 54(1), 31-53.

Prayoga, E. B.,\& Almilia, L. S. (2013). Pengaruh Struktur Kepemilikan dan Ukuran Perusahaan Terhadap Pengungkapan Manajemen Risiko. Jurnal Akuntansi dan Keuangan, 4(1), 1-19.

Probohudono, A. N., Tower, G., \& Rusmin, R. (2013). Risk disclosure during the global financial crisis. Social Responsibility Journal, 9(1), 124-136. https://doi. org/10.1108/17471111311307859

Rasid, S. Z. A., Rahim, A., Rahman, A., Khairuzzaman, W., \& Ismail, W. (2011). Management Accounting and Risk Management in Malaysian Financial Institutions. Managerial Auditing Journal, 26(7), 566-585. https:// dx.doi.org/10.1108/02686901111151314

Rasid, S. Z. A., (2014). Management Accounting Systems, Enterprise Risk Management and Organizational Performance in Financial Institutions. Asian Review of Accounting, 22(2), 128-144. https://doi.org/10.1108/ARA-03-2013-0022

Ratnawati, A. T. (2012). Analisis Faktor-Faktor yang Mempengaruhi Keberadaan Komite Manajemen Risiko (Risk Management Committee). Media Ekonomi dan Manajemen, 26(2), 66-78.

Razali, A. R., Yazid, A. S.,\& Tahir, I. M. (2012). TheDeterminants of Enterprise Risk Management (ERM) Practices inMalaysian Public Listed Companies. Journal of Social and DevelopmentSciences, 1(5), 202-207.

Said, R., Rahim, A.A.A., \& Hassan, R. (2018). Exploring the effects of corporate governance and human governance on management commentary disclosure. Social Responsibility Journal, 14(4), 843-858.https://doi. org/10.1108/SRJ-06-2017-0099

Sari, F. J. (2013). Implementasi Enterprise Risk Management pada Perusahaan Manufaktur di Indonesia. Accounting Analysis Journal, 2(2), 163-170.

Sarwono, A. A., Hapsari, D. W. H.,\&Nurbaiti,A. (2018). Pengaruh Profitabilitas, Leverage, dan Ukuran Perusahaan Terhadap Pengungkapan Manajemen Risiko. E-Proceeding of Management, 5(1), 769.

Solomon, J.F., Solomon, A., Norton, S. \& Joseph, N. (2000). A Conceptual Framework For Corporate Risk Disclosure Emerging From the Agenda For Corporate Governance Reform. British Accounting Review, 32(4), 447-478.

Sulistyaningsih \& Gunawan, B. (2016). Analisis Faktor-Faktor yang Mempengaruhi Risk Management Disclosure. Riset Akuntansi dan Keuangan Indonesia, 1(1), 1-11.

Taufani, M. T., Sodiq, H. N.,\& Wahid, A. (2016). Pengaruh Struktur Kepemilikan Terhadap Risk Management Disclosure.

Tessema, A. M. (2016). Mandatory hedging disclosure and risk management activities: the impact of product market competition.International Journal of Accounting\& Information Management, 24(1), 82-98. https://dx.doi. org/10.1108/IJAIM-05-2015-0028 